\title{
Preliminary results of a comparison between 4 pig breeds in chemical composition of fatty tissue and intramuscular fat content
}

\author{
Josiane BOUT ${ }^{(1)}$, J.P. GIRARD ${ }^{(2)}$, P. SELLIER ${ }^{(3)}$, J.P. RUNAVOT ${ }^{(1)}$, \\ Dominique SALORT ${ }^{(2)}$
}

(1) Institut Technique du Porc, Pôle Amélioration de l'Animal, B.P. 3, 36650 Le Rheu

(2) Institut National de la Recherche Agronomique, Station de Recherches sur la Viande, Theix 63122 Ceyrat

(3) Institut National de la Recherche Agronomique, Station de Génétique quantitative

et appliquée, 78350 Jouy-en-Josas

The purpose of this study was to evaluate the main breeds used in France regarding chemical composition of fatty tissue (leaf fat and backfat) and intramuscular fat content (Longissimus dorsi). The study involved 205 pigs from 4 breeds, i.e. two « dual-purpose " breeds (Large-White and French Landrace) and two "heavily-muscled " breeds (Pietrain and Belgian Landrace).

The heavily-muscled pigs, exhibiting low carcass fatness and relatively slow growth rate, gave a fatty tissue with higher water content, and the lipids of this tissue contained more unsaturated fatty acids. This feature was particularly evident in Pietrain pigs whose water content of backfat was on average $16 \mathrm{p} .100$ (and even up to $30 \mathrm{p} .100$ in some pigs), whereas the average water content did not exceed 12 p. 100 in the other breeds. Backfat with so much water was not suitable for processing. In addition, the Longissimus dorsi muscle from lean pigs, especially the Pietrain ones, contained more intramuscular fat than that from the "dual-purpose " breeds : 1.67 and 1.35 p. 100 in Pietrain and Belgian Landrace vs 1.24 and 1.19 in Large-White and French Landrace, respectively. This result can be explained by the lower growth rate exhibited by Pietrain and, to a lesser extent, by Belgian Landrace.

Correlations were calculated between the above chemical characteristics of fatty and muscle tissues on the one hand, carcass fatness and growth rate on the other hand. Water content and degree of unsaturation of fatty tissues in backfat and leaf fat appeared to be negatively correlated with growth rate and carcass fatness, whereas the two latter traits and lipid content of the Longissimus dorsi muscle were not correlated to a significant extent.

\section{Influence of cereal feeding (maize, wheat, barley) on backfat composition and organoleptic qualities of dry ham}

\author{
J. CASTAING ${ }^{(1)}$, F. GROSJEAN (2)
}

(1) Association Générale des Producteurs de Maïs, 122, boulevard Tourasse, 64000 Pau (2) Institut Technique des Céréales et Fourrages, 8, avenue du Président-Wilson, 75116 Paris

Bacon pigs between 25 and $100 \mathrm{~kg}$ live weight were fed maize-soyabean, wheat-soyabean or barley-soyabean according to a feeding scheme different for castrated males and females. After slaughter, the fatty acid composition of backfat and subcutaneous fat of hams was analysed. The quality of hams intended to be cooked was tested before processing into dry hams. After a 8-week or 6-month storage they were subjected to a taste panel.

The fatty acid composition of backfat depended on the diet, but was not affected by the sex of the animals. The linoleic acid content of backfat was 10.9 on an average with the maize-based diet versus 6.3 with diets based on wheat and barley. The $\mathrm{pH} 24 \mathrm{~h}$, the water holding capacity and the reflectance of the adductor muscle were not modified by the diet.

During storage, the weight loss of hams from pigs fed maize diets was lower than that of hams from pigs fed wheat or barley $(3.08-3.16$ and $3.19 \mathrm{~kg}$ for fresh hams weighing $8.8 \mathrm{~kg})$. 
In 8-week or 6-month stored hams, the taste panel did not notice any important difference according to the cereal either on lean or on fat (no rancid taste).

It may be concluded that monocereal diets (soyabean meal) have little effect on lean. As regards the fat, maize diets lead to a higher unsaturated fatty acid content of fat than wheat or barley diets, although the levels have no effect on the organoleptic qualities according to the taste panel.

\title{
Meat production from entire male pigs : Performance, meat quality and alternatives to boar taint
}

\author{
M. BONNEAU \\ Institut National de la Recherche Agronomique, Station de Recherches Porcines, \\ Saint-Gilles, 35590 L'Hermitage
}

The chemical composition of meat from entire male pigs is slightly different from that of castrates. The higher unsaturated fatty acid content of boar meat may be a drawback for some processed products. However, the main problem is boar taint. The latter is mainly due to the presence of skatole and androstenone responsible for the odour of faeces and urine, but the respective contribution of these compounds is still poorly understood.

Tainted meat may be used for processing. There is no entirely satisfactory method for sorting tainted meats on the slaughter line. A preliminary screening is possible using the measurement of Cowper's gland development. In some cases, such a screening might enable an increase in boar meat production. At the present time, there is no means of producing boars that could be certified as taint-free. Genetic and immunology offer promising ways of getting rid of the boar taint problem : further research is needed for an adaptation of these methods from the laboratory to the industry scale.

\section{GÉNÉTIQUE - GENETICS}

\section{Chromosomal abnormalities and " hypoprolificacy "}

\author{
P. POPESCU ${ }^{(1)}$, C. LEGAULT $^{(2)}$ \\ (1) Station de Cytogénétique; (2) Station de Génétique quantitative et appliquée \\ Institut de Recherche Agronomique. Centre de Jouy-en-Josas, Domaine de Vilvert, \\ 78350 Jouy-en-Josas
}

Owing to the great amount of research done in human medicine, the applications of cytogenetics in domestic mammals have spread out in the last decade. Following a brief survey of the methods which allow a more and more precise identification of chromosomes, this review is intended to give an overall presentation of porcine chromosomal abnormalities found in France and in the world, with special emphasis on their economic consequences and the means available for limiting their diffusion. In France, periodical analysis of data from the National Programme for Computerized Sow Herd Management allows to detect the so-called «hypoprolific » boars having sired litters whose average size of at least 6 litters is less than 8 piglets born alive. The proportion of these «suspected » boars among all breeding boars is about $1 / 1000$, and among those subjected 